Journal of Advanced College of Engineering and Management, Vol. 4, 2018

\title{
ASSESSMENT OF HYDRO-METEOROLOGICAL CONDITION OF KATHMANDU (NAGDHUNGA)-NAUBISE-MUGLING ROAD AND BRIDGES
}

\author{
Ram Krishna Regmi \\ Environment and Resource Management Consultant, Kathmandu, Nepal \\ Email Address: rkregmi@engineer.com
}

\begin{abstract}
The Kathmandu (Naghdhunga)-Naubise-Mugling (KNM) road has passed hilly area from Nagdhunga to Naubise (about 13\%) after passing Naubise the road alignment passes river valley of the Mahesh Khola and Trishuli River, initially the road alignment follows on left bank of the Mahesh Khola valley upto Galchhi before meeting with Trishuli River. After Galchhi, road alignment follows the left bank of the Trishuli River valley upto Mugling (about 87\%). The present study deals with the hydrological condition of the KNM road by analysing the existing hydro-meteorological data, reviewing the reports/documents of the previous studies and visiting the study area. The annual rainfall of the study area is found to be of increasing pattern. It is necessary to construct new crossing structures along with replacing some of the existing culverts in the existing road. Existing side drains are more or less adequate but the capacity might to be increased during the improvement works. In the proposed new alignment 113 cross drains are necessary to construct and proposed side drains will be adequate for passing the design flood. Some of the stretches of the existing road are very close to the river and are vulnerable of being toe cutting and flooding from the river.
\end{abstract}

Keywords: KNM road; hydrological condition; hydro-meteorological data; rainfall; design flood

\section{Introduction}

Nepal is geographically a small landlocked country, situated between India and China. The major road corridor from Kathmandu to Birgunj connects the capital city with national border to India. Nepal government has the responsibility of improving the performance of road corridor from Birgunj to Kathmandu to improve the trade. The $276 \mathrm{~km}$ stretch of road from Birgunj to Kathmandu is part of Asian Highway (AH-42) and is most important trade corridor in Nepal. Road improvement, upgrades and construction of new alignments will be inevitable to maintain good transportation system, enhancing road safety and improvement of freight transportation, correspondingly, minimizing and reducing time and costs of transportation, resources and energy on the way from Kathmandu to the national border with India in Birgunj.

The improvement of Kathmandu-Mugling section of existing highway is one of major strategic projects, ensuring efficiency of the entire road system, having enormous value for national economy. This section of the road is one of the key elements, providing connectivity not only to Terai Region on the way to Indian border, but also to one of the magnificent places of touristic destinations in the country. Pokhara and Annapurna Conservation Area. More tourists will be able to visit this area, likely, after improvement of the existing road and improved accessibility of the one of the major touristic destinations in the country. Further, improvement of KNM highway will facilitate development of physical infrastructures, thus, contributing to local and regional development, economic initiatives and improvement of local wellbeing.

The present study deals with the hydrological condition of the KNM road located in Kathmandu, Dhading, Chitwan and Gorkha district of state number 3 included in Nepal India Regional Trade and Transport Project (NIRTTP) project in Nepal. The project road starts at Naghdhunga and ends at Mugling covering a total length of $96 \mathrm{~km}$. The alignment passes through Naghdhunga, Naubise, Khanikhola, Mahadevbesi, Galchi, Baireni, Malekhu, Benighat, Kurintar to reach Mugling. The KNM 
road alignment is an existing state road; with proposed new alignments such as Sisnekhola-Dharke approx- $11.2 \mathrm{~km}$ and Bishaltar-Phisling $15.3 \mathrm{~km}$. The present road section is proposed for improvement and upgradation to two lane carriageway configurations with shoulders and side drains. The map of the study area has been presented in Figure 1.
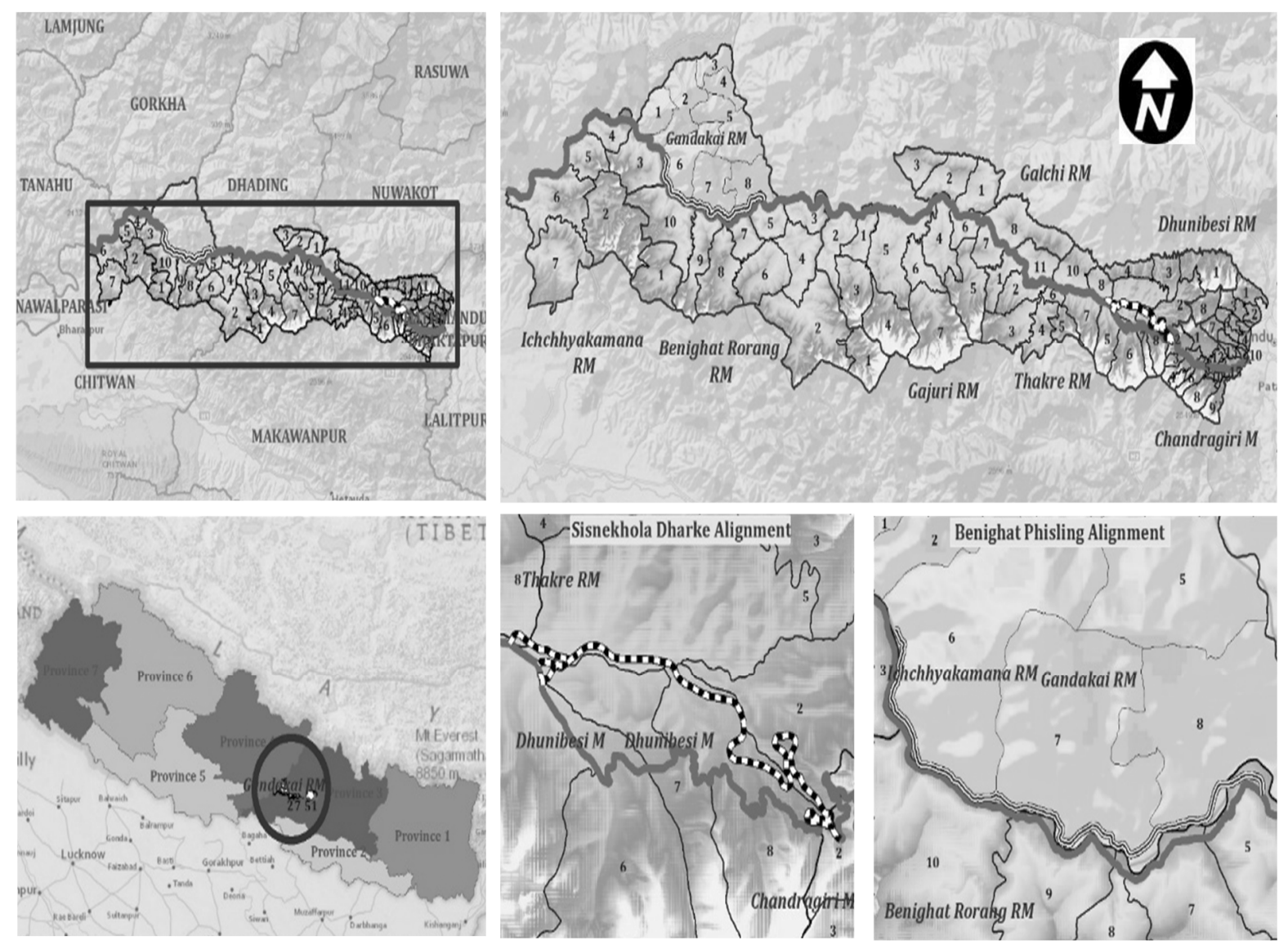

Legend $\mathbf{m}$ Sisine Khola Dharke Alignment $=$ Benighat Fishling Aligmment
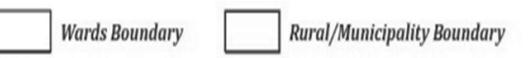

Existing Highway

Fig 1: Study Area Map

\section{Topography and Geomorphology}

The KNM road and its alternative alignment passes through the hilly area of Kathmandu, Dhading, Chitwan and Gorkha district in Central Development Region of the country. The proposed road alignment lies in the Middle Mountain (Lesser Himalaya). The elevation ranges from $1,500 \mathrm{~m}$ (Nagdhunga) to $265 \mathrm{~m}$ (Mugling) from above mean sea level (amsl). Nagdhunga is the highest point of the alignment, with most villages lying at about $1500 \mathrm{~m}$ above sea level.

Overall topography of road alignment is rolling type with ascending and partially descending at different sections. The road alignment has passed hilly area from Nagdhunga to Naubise after Naubise the road alignment passes river valley of the Mahesh Khola and Trishuli River, initially the road alignment follows bank of the Mahesh Khola valley upto Galchhi before meeting with Trishuli River. After Galchhi, road alignment follows the left bank of the Trishuli River valley upto Mugling.

The road alignment starts from Nagdhunga (1,500 amsl) of boarder of Kathmandu and Dhading district and ends at Mugling (256 amsl) of Chitwan district, whereas the Sisne Khola has elevation of $1320 \mathrm{~m}$ amsl. The existing road runs from Nagdhunga to Mahadev Besi on the north aspect, after then the road traverses on the northeast aspect upto Belkhu. From Belkhu to Majhimtar the road alignment runs on the again north aspect. The alignment traverses on the north to northeast slope from 
Majhimtar to Mugling. The proposed new alignment between Sisne Khola and Dharke the road has the south to southwest aspect.

The road alignment lies in the Middle Mountain (Midland zone, Lesser Himalaya). The elevation ranges from 1,500 $\mathrm{m}$ (Nagdhunga) to $265 \mathrm{~m}$ (Mugling) from above mean sea level (amsl). Overall topography of road alignment is rolling type with ascending and partially descending at different sections. The alignment crosses major rivers like the Sirke Khola, Khani Khola, Naubise Khola, Sugure Khola, Sopyang Khola, Juge Khola, Agra Khola, Phedi Khola, Kheste Khola, Machhedi Khola, Belkhu Khola, Galaudi Khola, Malekhu Khola, Gomati Khola, Charaudi Khola, Khataudi Khola, Hugdi Khola, Mauwa Khola, Chum Khola, Dahaki Khola, Barban Khola and Nagdi Khola. The road alignment follows more than $90 \%$ along the river valley of the Mahesh Khola and Trishuli River. The road follows on the left bank of the valley. The road alignment runs 5 to $150 \mathrm{~m}$ above from the riverbed of the Mahesh Khola and Trishuli River.

The road alignment starts from Nagdhunga $(1,500 \mathrm{amsl})$ of boarder of Kathmandu and Dhading district and ends at Mugling (256 amsl) of Chitwan district whereas the Sisne Khola outlet of the proposed tunnel road outlet, has elevation of $1320 \mathrm{~m}$ amsl. The road runs from Nagdhunga to Mahadev Besi on the north aspect, after then the road traverses on the northeast aspect upto Belkhu. From Belkhu to Majhimtar the road alignment runs on the again north aspect, from Majhimtar to Mugling, the alignment traverses on the north to northeast slope. The elevation with chainage of the main references is presented in Table 1.

Table 1: Elevation with chainage of locations

\begin{tabular}{|c|c|c|c|}
\hline SN & Location & Chainage & Elevation \\
\hline 1 & Nagdhunga & $0+000$ & 1500 \\
\hline 2 & Sisne Khola & $3+250$ & 1320 \\
\hline 3 & Naubise & $12+000$ & 840 \\
\hline 4 & Dharke & $14+500$ & 800 \\
\hline 5 & Mahadev Besi & $23+000$ & 500 \\
\hline 6 & Galchhi (Baireni) & $34+000$ & 428 \\
\hline 7 & Belkhu & $40+500$ & 400 \\
\hline 8 & Gajuri & $49+500$ & 400 \\
\hline 9 & Malekhu & $56+500$ & 400 \\
\hline 10 & Benighat & $62+500$ & 375 \\
\hline 11 & Bahuntar & $63+000$ & 380 \\
\hline 12 & Bishaltar & $65+500$ & 380 \\
\hline 14 & Majhimtar & $73+000$ & 320 \\
\hline 15 & Kuringhat & $86+000$ & 300 \\
\hline 16 & Mugling & $94+000$ & 268 \\
\hline
\end{tabular}




\section{Climate Change Impacts}

Climate in the project area varies from sub-tropical to temperate and sub-alpine type. Maximum average temperature of the project districts is more than $30^{\circ} \mathrm{C}$ and minimum average temperature less than $10^{\circ} \mathrm{C}$.

According to IPCC (2013) global mean surface temperature in the near-term future (2016-2035) compared to reference period of $1986-2005$ will be in the range of 0.3 to $0.7^{\circ} \mathrm{C}$. Similarly, the area encompassed by monsoon systems will increase over the $21^{\text {st }}$ century and monsoon season is likely to intensify due to the increase in atmospheric moisture. Nepal has been identified as one of four global hotspots for climate change risk, which is a result of complex and extreme topography, quick responding catchments with intense seasonal and climatic variability (MoSTE, 2014). NCVST (2009) suggested that mean annual temperature across Nepal is projected to increase by 0.5 to $2^{\circ} \mathrm{C}$ by $2030 \mathrm{~s}$; 1.7 to $4.1^{\circ} \mathrm{C}$ by $2060 \mathrm{~s}$; and 3 to $6.3^{\circ} \mathrm{C}$ by $2090 \mathrm{~s}$. The study suggested that annual precipitation will change by -34 to $+22 \%$ by $2030 \mathrm{~s} ;-36$ to $+67 \%$ by $2060 \mathrm{~s}$; and -43 to $+80 \%$ by 2090 s. The rainfall analysis of the present study shows decreasing trend for the study area. An assessment of future floods in the Bagmati River basin carried out by Mishra and Herath (2014) has predicted that in future period (2075 - 2099), magnitude of 2 to 100 year return period floods will increase by 24 to $40 \%$. In United Kingdom, Department of Communities and Local Government has recommended to make allowance of $+10 \%$ till 2025 period and $+20 \%$ for 2025 to 2115 period in peak river flows to account climate change.

Even though present rainfall analysis shows decreasing trend of rainfall for the study area, different studies (Viviroli et al., 2011; Nepal \& Shrestha, 2015; Nepal, 2016; etc.) have suggested that extreme events in future are likely to be more frequent and magnitude of such events are likely to increase. Increased extreme rainfall could trigger landslides in several stretches of the road alignment and bring large flood discharge which can wash away bridges and other cross drainage structures along the alignment (like during 1993 flood event). Side drains may be inadequate to quickly remove water from the road surface. Similarly, high flood water can cause toe cutting of the road slopes. It is advisable to consider these aspects during design. However, it will lead to increase in sizes of the structures. In Nepal, guidelines for considering climate change in the design is not available currently. However, increasing the design discharge to cover climate change uncertainty and/or designing cross drainage structures and side drains at higher return period will help reducing their vulnerability from extreme events (DoR, 2017).

Dhading, Gorkha and Chitwan districts are ranked as having high vulnerability to climate change; where the Kathmandu District is ranked as highly vulnerable according to an overall climate change vulnerability index. Nepal's low level of development and complex topography renders it vulnerability to climate change. The ongoing climate change and changes projected to occur are likely to have impacts on different sectors of Nepal. The sensitive sectors to climate change are agriculture, forestry, water and energy, urban development and infrastructure, tourism, some types of industry, overall livelihoods and economy. More than 1.9 million people are highly vulnerable and 10 million are increasingly at risk to climate change, and this number will likely increase significantly in the future (MoE, 2010).

A study by GoN (2017) found that the annual pattern of temperature in Kathmandu and Hilly area was observed to be increasing in the rate of 0.0514 degrees per year. The highest temperature recorded in $2010\left(20.25^{\circ} \mathrm{C}\right)$ whereas the lowest temperature was recorded in 1997 which was $17.97^{\circ} \mathrm{C}$. The overall pattern of seasonal temperatures was also found to be increasing. The rate of increment of premonsoon, monsoon, autumn and winter temperature were recorded to be 0.076, 0.042, 0.039and 0.046degrees per year, respectively. The annual rainfall of the Hilly area of the Birgunj-Hetauda- 
Narayanghat-Muglin-Kathmandu corridor showed increasing pattern. The rate of increase was observed to be $6.487 \mathrm{~mm}$ per year with maximum rainfall in $2013(1899.3 \mathrm{~mm})$ and minimum rainfall in $1999(1067.9 \mathrm{~mm})$. All the seasons showed increasing trend of rainfall.

\section{Climate and Hydrology}

Nepal has a very sharp relief topography leading to unusually high inter-variability of climate and hydrology. There are the two types of rainfall in Nepal. Summer monsoon rain usually begins in the second week of May and last until the end of September and winter monsoon generally occurs in between the month of October to May. The summer monsoon originating from the Bay of Bengal and the winter monsoon originating from the Mediterranean Sea. There is direct influence of rainfall in the discharge of water volume in the rivers of Nepal. Nepalese rivers have been estimated to be draining 174 billion cubic meters of water per year as surface run-off and are based on an average annual rainfall of about $1400 \mathrm{~mm}$.

\subsection{River System}

The Kathmandu-Naubise-Mugling road is located in mid-hill areas. There are 27 rivers and rivulets along Kathmandu (Nagdhunga)-Naubise-Mugling and are tributaries of Trisuli River Basin. They are entirely dependent on rainfall for their runoff. Rivers and rivulets crossing the KNM road are listed in Table 2.

Table 2: Rivers/rivulets along KNM roadside

\begin{tabular}{|l|l|l|}
\hline 1. Mahesh Khola & 10. Khesre Khola & 19. Gomati Khola \\
\hline 2. Thare Khola & 11. Trishuli Ganga Nadi & 20. Bisural Khola \\
\hline 3. Jhapre Khola & 12. Chiraudi Khola & 21. Charaudi Khola \\
\hline 4. Sikre Khola & 13. Belkhu Khola & 22. Khatauti Khola \\
\hline 5. Khani Khola & 14. Trishuli River & 23. Hughdi Khola \\
\hline 6. Naubise Khola & 15. Pokhare Khola & 24. Mauwa Khola \\
\hline 7. Agra Khola & 16. Galaudi Khola & 25. Chum Khola \\
\hline 8. Phedi Khola & 17. Malekhu Khola & 26. Dahaki Khola \\
\hline 9. Machhedi Khola & 18. Kadam Khola & 27. Barban Khola \\
\hline
\end{tabular}

The existing road is mainly following the left bank of Trisuli River with 26 major/minor bridges, most of them are built on tributaries of the Trisuli River. Additionally, a lot of small seasonal streams are crossing the existing road, where pipe and slab culverts of different sizes are provided. Inadequate sizes of drains have been identified at some places and recommendations are made to replace them by larger size (DoR, 2017).

There are 7 minor bridges over Mahesh Khola and its tributary, and Khani Khola along new alignment from Sisne to Dharke (DoR, 2017). The another proposed alignment from Benighat to Kurintar has 2 major bridges over Trisuli River and 8 minor bridges on its tributary. Many seasonal streams are also crossing the new alignments.

\subsection{Meteorology}

In order to provide some information on the climate patterns of the study area, an analysis of 30 years of past recorded meteorological data on temperature and rainfall were analyzed. 


\section{i) Temperature}

Kathmandu Airport $\left(27^{\circ} 42^{\prime}\right.$ N, $85^{\circ} 22^{\prime}$ E) - Index No. 1030 is the weather station located in close proximity of the study area. Analysis of 49 years of data from Kathmandu Airport records, recorded in DHM (1968-2016), shows that the temperature pattern was observed to be increasing in the rate of $0.0508^{\circ} \mathrm{C}$ per year. The yearly average highest temperature was recorded in $2010\left(20.3^{\circ} \mathrm{C}\right)$ whereas the yearly average lowest temperature was recorded in $1971\left(17.4^{\circ} \mathrm{C}\right)$. The overall patterns of seasonal temperatures were also found to be increasing. The rate of increase in spring, monsoon, autumn and winter temperatures were recorded to be $0.0539,0.0364,0.0504$ and $0.0625^{\circ} \mathrm{C}$ per year, respectively. The annual, spring, monsoon, autumn and winter patterns of temperature is presented in Figure 2.
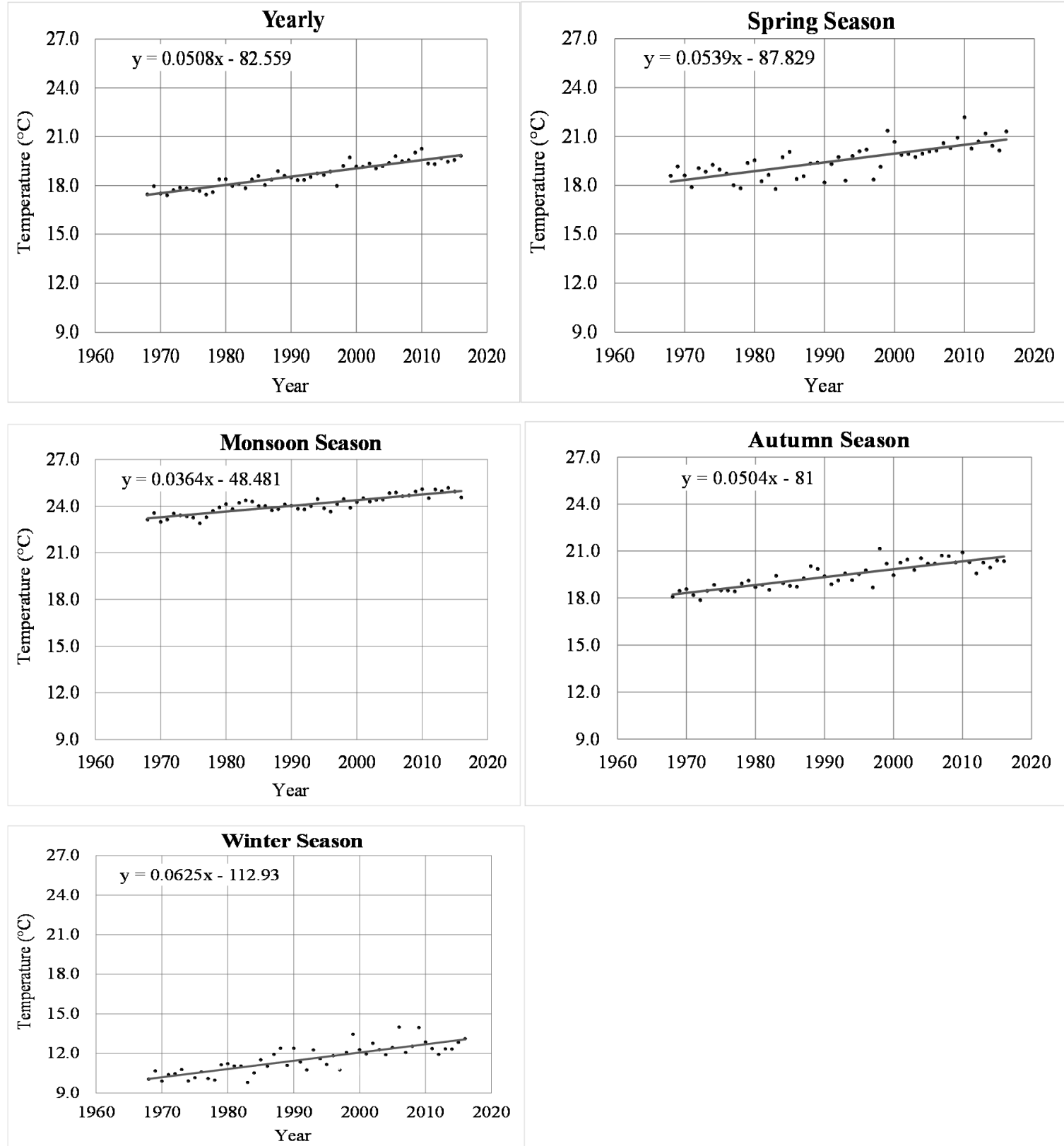

Fig. 2: Annual, spring, monsoon, autumn and winter patterns of temperature

\section{ii) Rainfall}

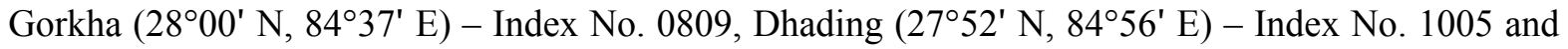
Thankot $\left(27^{\circ} 41^{\prime} \mathrm{N}, 85^{\circ} 12^{\prime} \mathrm{E}\right)$ - Index No. 1015, are the rainfall stations located within and in close 
proximity of the project area. Analysis of 49 years of data, recorded in DHM (1968-2016), shows that the rainfall pattern of the study area indicates that the annual rainfall of the study area is of decreasing pattern. The rate of decrease was observed to be $10.408 \mathrm{~mm}$ per year with maximum rainfall in 1978 $(2501.4 \mathrm{~mm})$ and minimum rainfall in $2015(1207.5 \mathrm{~mm})$. The overall patterns of seasonal rainfalls were also found to be decreasing. The rate of decrease in spring, monsoon, autumn and winter rainfalls were recorded to be $0.7722,5.6198,3.7369$ and $0.2786 \mathrm{~mm}$ per year, respectively. The annual, spring, monsoon, autumn and winter patterns of rainfall is presented in Fig. 3.
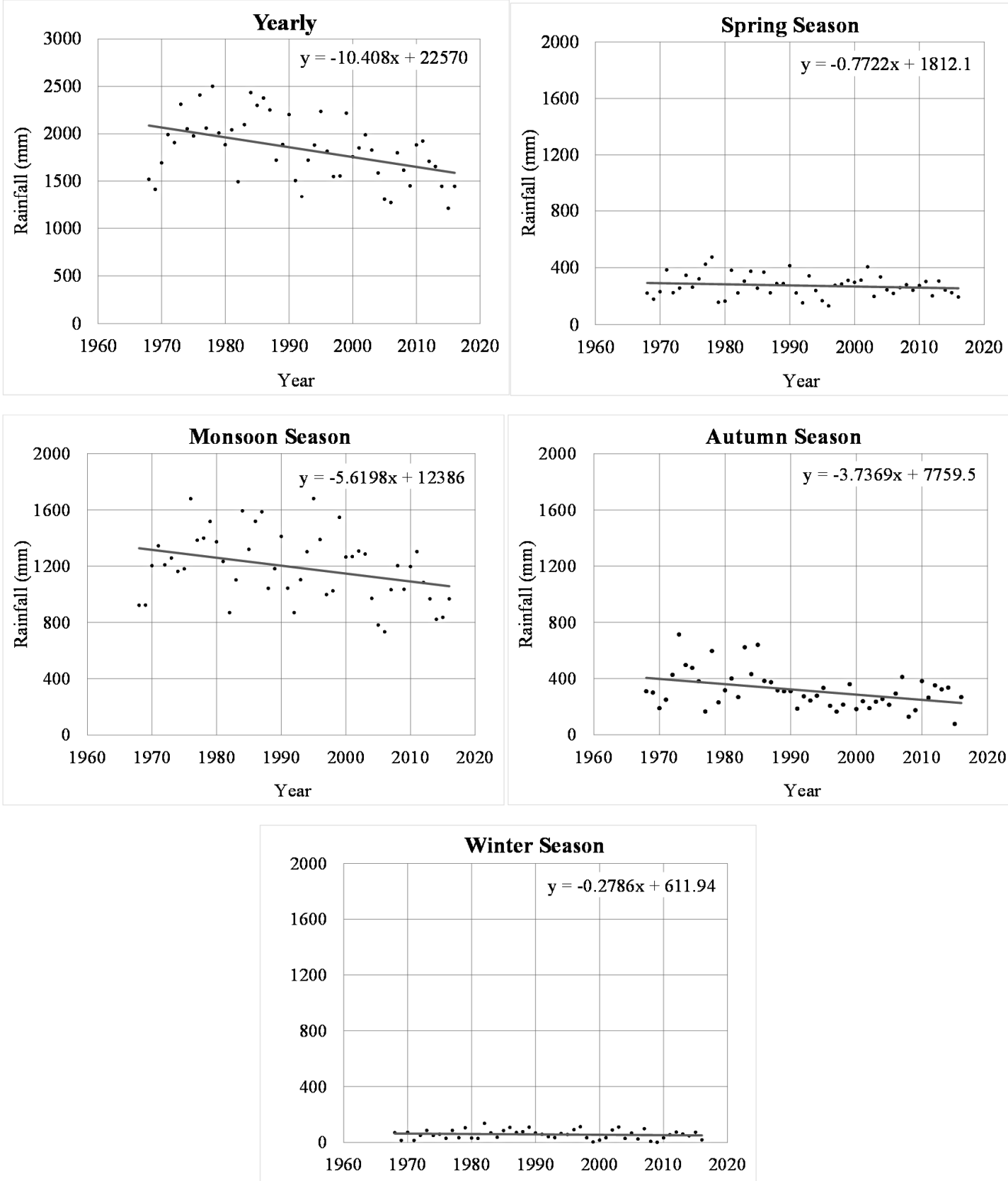

Fig. 3: Annual, spring, monsoon, autumn and winter patterns of rainfall

\subsection{Hydrology}

In order to provide some information on the discharge patterns of the study area, an analysis of past recorded discharge data of Trishuli River at Betrawati $\left(27^{\circ} 58^{\prime} \mathrm{N}, 85^{\circ} 11^{\prime} \mathrm{E}\right)$ - Station No. 447 from 
1977 to 2015 (39 years) and Kali Khola (2750' N, 84³3' E) - Station No. 449.91 from 1994 to 2015 (22 years) were analyzed. The discharge pattern of the Trisuli River indicates that the annual flow is of increasing pattern (Fig. 4), whereas the annual instantaneous maximum flow is of decreasing pattern (Fig. 5). The rate of increase at Betrawati was observed to be 0.0289 cumecs per year with maximum discharge in 2003 (275.1 cumecs) and minimum discharge in 2009 (142.2 cumecs). Similarly, the rate of increase at Kali Khola was observed to be 0.0289 cumecs per year with maximum discharge in 2003 (1068.8 cumecs) and minimum discharge in 2001 (654.6 cumecs). The rate of decrease of instantaneous maximum flow at Betrawati was observed to be 1.2134 cumecs per year and that of Kali Khola was observed to be 14.912 cumecs per year.

According to the rainfall trend analysis, the annual average rainfall of the study area is decreasing at the rate of $10.408 \mathrm{~mm}$ per year (Fig. 3), however the Trishuli River shows increasing trend. But the annual trend of maximum instantaneous flow of this river follows the decreasing trend of rainfall. Trishuli River is snow-fed river. Annual increasing trend of temperature (Fig. 2) of the study area causes increase in snow melt trend. It indicates that the increasing trend of annual flow this river is due to the contribution of snow melt in runoff, however the maximum instantaneous flow is of direct contribution of rainfall rather than snow melt runoff.
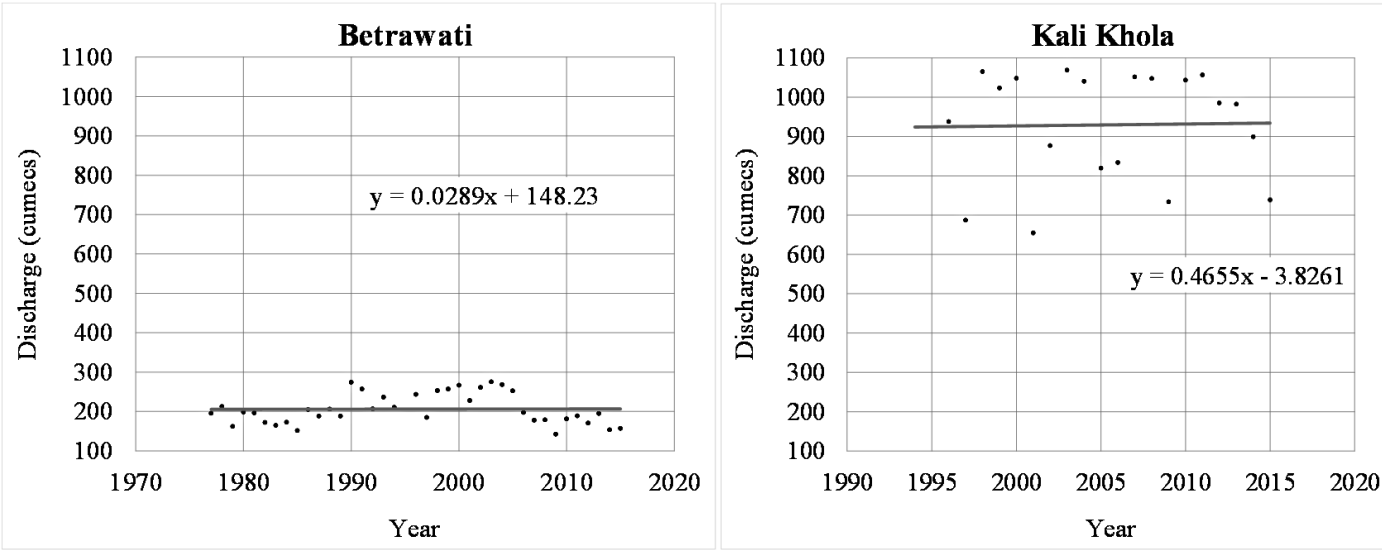

Fig. 4: Annual patterns of river flow
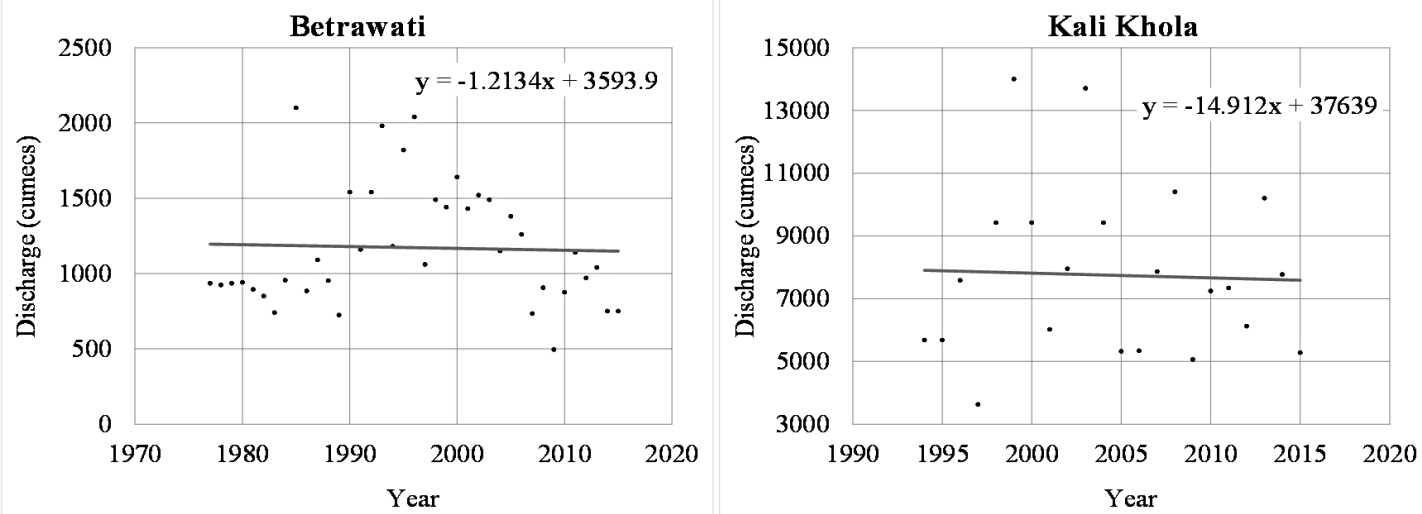

Fig. 5: Annual patterns of instantaneous maximum flow 


\subsection{Flood Estimation for Drainage Structures}

\section{i) Existing Road Alignment}

Taking 100 years return period, DoR (2017) estimated the design flood discharge passing through the existing bridges using rational formula and were compared with flood discharge estimated using several reqional/ernipircal methods (Table 1).

Table 1: Design flood estimation for existing bridges in the existing road alignment (cumecs)

\begin{tabular}{|c|c|c|c|c|c|c|c|c|}
\hline $\bar{\sim}$ & 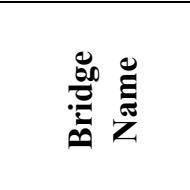 & 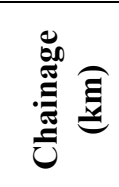 & 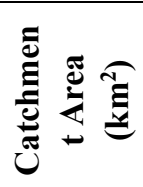 & 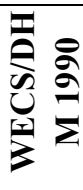 & 䇂离 & $\underbrace{0}_{0}$ & 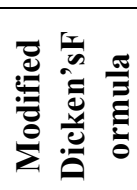 & 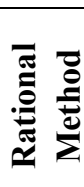 \\
\hline 1 & Khatripauwa & $4+139$ & 0.8 & 22 & 17 & 10 & 4 & 13 \\
\hline 2 & Naubise & $12+449$ & 16.1 & 118 & 153 & 92 & 83 & 176 \\
\hline 3 & Ganesh & $2+965$ & 4.0 & 48 & 57 & 36 & 22 & 57 \\
\hline 4 & Sopyang & $5+096$ & 6.0 & 61 & 75 & 47 & 32 & 70 \\
\hline 5 & AgraKhola & 1 & 111.8 & 470 & 618 & 410 & 473 & 495 \\
\hline 6 & Khahare & $12+376$ & 1.6 & 29 & 29 & 21 & 9 & 26 \\
\hline 7 & Phedi & $14+453$ & 3.1 & 41 & 46 & 63 & 17 & 50 \\
\hline 8 & Dangdunge & $14+735$ & 7.9 & 73 & 91 & 117 & 42 & 86 \\
\hline 9 & Kheste & $18+165$ & 22.8 & 150 & 197 & 257 & 114 & 165 \\
\hline 10 & Machedi & $19+484$ & 1.3 & 27 & 25 & 31 & 7 & 25 \\
\hline 11 & Gardo & $23+128$ & 4.8 & 53 & 64 & 85 & 26 & 80 \\
\hline 12 & Jundi & $24+989$ & 2.5 & 36 & 40 & 54 & 14 & 39 \\
\hline 13 & Chiraudi & $26+488$ & 12.0 & 96 & 124 & 152 & 63 & 100 \\
\hline 14 & Belkhu & $28+803$ & 88.0 & 395 & 520 & 653 & 383 & 424 \\
\hline 15 & Pokhare & $33+155$ & 5.3 & 57 & 69 & 92 & 29 & 64 \\
\hline 16 & Galaudi & $36+316$ & 19.7 & 135 & 177 & 228 & 99 & 150 \\
\hline 17 & Soti & $38+384$ & 1.7 & 30 & 30 & 39 & 9 & 32 \\
\hline 18 & Malekhu & $43+379$ & 101.5 & 438 & 576 & 711 & 434 & 435 \\
\hline 19 & Gomati & $49+942$ & 8.0 & 74 & 93 & 119 & 43 & 95 \\
\hline 20 & Charaudi & $55+246$ & 46.6 & 249 & 329 & 439 & 217 & 311 \\
\hline 21 & Khatauti & $58+186$ & 6.8 & 66 & 83 & 109 & 37 & 96 \\
\hline 22 & Hugdi & $61+706$ & 53.1 & 274 & 362 & 459 & 244 & 303 \\
\hline 23 & Mowa & $65+887$ & 9.6 & 83 & 105 & 120 & 51 & 101 \\
\hline 24 & Dahaki & $72+344$ & 1.0 & 24 & 21 & 23 & 5 & 17 \\
\hline 25 & Barbang & $73+275$ & 5.8 & 60 & 73 & 92 & 1 & 63 \\
\hline 26 & Nagdi & $80+182$ & 6.8 & 66 & 82 & 102 & 37 & 69 \\
\hline
\end{tabular}

Note: For Khatripauwa and Naubise Bridges, $0+000$ is at Nagdhunga while for rest of the bridges, $0+000$ is at Naubise 
Cross drains will be designed for 50 years return period flood (DoR, 2017). Using Rational formula for discharge estimation of cross drains, this study pointed out the necessity of new crossing structures along with replacing of existing culverts which are inadequate to pass design discharge.

DoR (2017) also found that the existing side drains are more or less adequate for 25 years return period flood but might to be increased for increased return period of flood. In any case during the improvement works, these side drains will be dismantled and the new side drains will be constructed.

\section{ii) Proposed Road Alignment}

For the proposed new alignment of Sisne-Dharke section, 7 minor bridges are recommended in the Mahesh Khola and its tributaries, and Khani Khola (DoR, 2017) as presented in

Table 2.

Table 2: Design flood estimation for existing bridges in the existing road alignment (cumecs)

\begin{tabular}{|c|c|c|c|c|}
\hline SN & Chainage & Catchment Area & 100 Years Flood (cumecs) & Recommended Bridge Span \\
\hline 1 & $7+902$ & 2.76 & 43 & 10 \\
\hline 2 & $8+980$ & 4.9 & 65 & 15 \\
\hline 3 & $9+995$ & 8.62 & 110 & 20 \\
\hline 4 & $10+508$ & 8.87 & 107 & 20 \\
\hline 5 & $11+980$ & 34.1 & 218 & 35 \\
\hline 6 & $14+860$ & 43.1 & 276 & 50 \\
\hline 7 & $15+120$ & 27.28 & 175 & 50 \\
\hline
\end{tabular}

Source:DoR (2017)

Similarly, for the proposed new alignment of Benighat - Kurintar section, 2 major bridges over Trisuli and 8 minor bridges in its tributaries are recommended (DoR, 2017) as presented in Table 3.

Table 3: Recommended bridges along new alignment of Benighat-Kurintar section

\begin{tabular}{|c|c|c|c|c|}
\hline SN & Chainage & $\begin{array}{c}\text { Catchment Area } \\
\left(\mathbf{k m}^{2}\right)\end{array}$ & $\begin{array}{c}\mathbf{1 0 0} \text { Years Flood } \\
\text { (cumecs) }\end{array}$ & $\begin{array}{c}\text { Recommended Bridge Span } \\
(\mathbf{m})\end{array}$ \\
\hline 1 & $1+100$ & 11,670 & 14,666 & 250 \\
\hline 2 & $1+635$ & 4.65 & 71 & 15 \\
\hline 3 & $3+796$ & 4.16 & 60 & 15 \\
\hline 4 & $4+571$ & 5.40 & 71 & 15 \\
\hline 5 & $6+310$ & 4.38 & 61 & 15 \\
\hline 6 & $9+270$ & 4.89 & 57 & 15 \\
\hline 7 & $14+705$ & 3.60 & 56 & 15 \\
\hline 8 & $15+953$ & 9.32 & 96 & 20 \\
\hline 9 & $17+176$ & 3.77 & 55 & 15 \\
\hline 10 & $19+350$ & 11,867 & 14,913 & 250 \\
\hline
\end{tabular}

Source: DoR (2017) 
Using Rational formula for discharge estimation of cross drains, DoR (2017) pointed out the necessity of 46 cross drains for Sisne to Dharke section; and 67 cross drains for Benighat to Kurintar. This study also revealed that the side drains proposed in new road sections will be adequate to pass the floods of 25 years return period.

\subsection{Identification of Locations for River Training works}

The existing road alignment from Naubise to Mugling is in the left bank of Mahesh River (up to Galchhi) and Trishuli River (up to Mugling). Some of the stretches of the existing road are in close proximity of the river and are vulnerable of being toe cutting and flooding from the river. Such locations are identified and recommended for the required protection work (DoR, 2017). Table 4 summarizes the location and length of protection work required.

Table 4: Recommended bridges along new alignment of Benighat-Kurintar section

\begin{tabular}{|c|c|c|c|}
\hline SN & Chainage $(\mathrm{km})$ & Length of Protection Work $(\mathrm{m})$ & \multicolumn{1}{c|}{ Remarks } \\
\hline 1 & $12+200$ to $12+400$ & 200 & Left bank of Mahesh river \\
\hline 2 & $14+400$ to $14+600$ & 200 & Left bank of Mahesh river \\
\hline 3 & $16+050$ to $16+200$ & 150 & Left bank of Mahesh river \\
\hline 4 & $16+450$ to $16+850$ & 400 & Left bank of Mahesh river \\
\hline 5 & $17+900$ to $18+100$ & 200 & Left bank of Mahesh river \\
\hline 6 & $26+100$ to $26+200$ & 100 & Left bank of Mahesh river \\
\hline 7 & $32+400$ to $33+100$ & 700 & Left bank of Mahesh river \\
\hline
\end{tabular}

Source: DoR (2017)

\section{Conclusion}

The KNM road passing hilly area from Nagdhunga to Naubise after passing Naubise the road alignment passes river valley of the Mahesh Khola and Trishuli River with the increasing pattern of annual rainfall. The present study aims to identify the hydrological condition of the KNM road. In the existing road alignment, construction of new crossing structures along with replacing some of the existing culverts are necessary for discharge of 50 years return period. Existing side drains are more or less adequate for discharge of 25 years return period but the capacity might to be increased during the improvement works. 7 minor bridges are recommended in the new alignment of Sisne-Dharke section, and 2 major bridges over Trisuli and 8 minor bridges in its tributariesin Benighat - Kurintar section. Similarly, 46 cross drains for Sisne to Dharke section; and 67 cross drains for Benighat to Kurintar. Existing road section, in close proximity of the river, are vulnerable of being toe cutting and flooding from the river. 


\section{References}

1. DoR (2017). "Feasibility study for improvement of Kathmandu (Nagdhunga)-NaubiseMugling Road and Bridges", Final Feasibility Report, Department of Roads Foreign Cooperation Branch, Ministry of Physical Infrastructure and Transport, Government of Nepal.

2. GON (2017). "Project Area Report (Including Baseline Information and Scoping For SESA Study)”,Nepal India Regional Trade and Transport Project (NIRTTP), Department of Roads Foreign Cooperation Branch, Ministry of Physical Infrastructure and Transport, Government of Nepal.

3. IPCC (2013). Climate Change 2013: "The Physical Science Basis, Contribution of Working Group I to the Fifth Assessment Report of the Intergovernmental Panel on Climate Change" [Stocker, T.F., D. Qin, G.-K. Plattner, M. Tignor, S.K. Allen, J. Boschung, A. Nauels, Y. Xia, V. Bex and P.M. Midgley (eds.)], Cambridge University Press, Cambridge, United Kingdom and New York, NY, USA, 1535 pp.

4. Mishra, B.K., \& Herath, B. (2015). "Assessment of Future Floods in the Bagmati River Basin of Nepal Using Bias-Corrected Daily GCM Precipitation Data", Journal of Hydrologic Engineering, 20 (8).

5. MoSTE (2014). "Nepal Climate Change Program (CCP) Results Management Framework (RMF)" 2013-2020, Ministry of Science, Technology and Environment.

6. MoE (2010). "National adaptation programme of action (NAPA) to climate change", Ministry of Environment, Government of Nepal.

7. NCVST (2009). "Vulnerability through the eyes of vulnerable: Climate change induced uncertainties and Nepal's Development Predicaments", Institute for Social and Environmental Transition-Nepal (ISET-N, Kathmandu) and Institute for Social and Environmental Transition (I SET, Boulder, Colorado) for Nepal Climate Vulnerability Study Team (NCVST) Kathmandu.

8. Nepal, S. (2016). "Impacts of climate change on the hydrological regime of the Koshi river basin in the Himalayan region", Journal of Hydro-environment Research, 10, pp 76-89.

9. Nepal, S., Shrestha, A.B. (2015). "Impact of climate change on the hydrological regime of the Indus, Ganges and Brahmaputra river basins: a review of the literature", International Journal of Water Resources Development, Routledge, 31, pp 201-218.

10. Viviroli, D., Archer, D.R., Buytaert, W., Fowler, H.J., Greenwood, G.B., Hamlet, A.F., et al. (2011). "Climate change and mountain water resources: Overview and recommendations for research, management and policy", Hydrology and Earth System Sciences, 15, pp 471-504. 